\title{
DENDROCHRONOLOGICAL STUDIES OF WOOD FROM MEDIAEVAL MINES OF POLYMETALLIC ORES IN LOWER SILESIA (SW POLAND)
}

\author{
ELŻBIETA SZYCHOWSKA-KRĄPIEC \\ AGH - University of Science and Technology, Department of Geology, \\ Geophysics and Environmental Protection, \\ 30-059 Cracow, Mickiewicza 30, Poland
}

\begin{abstract}
The paper presents results of dendrochronological dating of wood encountered in abandoned mines in the eastern part of Lower Silesia. The research was carried out in gold mines in Złoty Stok, Głuchołazy, and Zlate Hory, a polymetallic-ore mine in Marcinków as well as old mines in the Sowie Mts: the Silberloch adit, an adit on the hillside of Mała Sowa, a graphite mine, and the silver and lead mine Augusta. Altogether 69 samples were taken from timbers of coniferous tree species: Pinus sylvestris, Abies alba, Picea abies and Larix decidua. The oldest wood, from the turn of the fifteenth and sixteenth centuries was encountered in the gold mines in Zlate Hory and Głuchołazy. In the gold mine in Złoty Stok, graphite mine in Sowie Mts and in Marcinków there was identified wood from the seventeenth and eighteenth centuries. Generally, timbers from the nineteenth century were prevailing, and in three cases there was even encountered relatively young twentieth-century wood in the gold mine in Złoty Stok and in the Silberloch adit. The analyses carried out were only preliminary. Broader, interdisciplinary investigations, including dendrochronology, archaeology, geology, mining, and palaeobotany, would substantially contribute for learning the history of the mining in the whole region.
\end{abstract}

Keywords: dendrochronological dating, tree-ring analysis, mines, SW Poland

\section{INTRODUCTION}

Dendrochronological studies of wood occurring in old mines in Poland have a short, only several-year history. The first pioneering studies from this scope were carried out in the Wieliczka salt mine at the end of 1980s. Ten years later, at the end of 1990s detailed dendrochronological sampling was made in this historic mine, in particular on the first, oldest level of the mine, where almost 300 samples were taken from wooden casings of the oldest, but still accessible mining chambers (Szychowska-Krapiec, 2003a). Dendrochronological studies were also performed in the Bochnia salt mine, where over 300 wood samples were taken from timbering of chambers situated on seven mining levels (SzychowskaKrapiec, 2003b). These studies resulted in a number of absolute datings, ranging from the fifteenth to the twentieth century. Both salt mines belong to the oldest mining

Corresponding author: E. Szychowska-Krapiec e-mail: szycha@geol.agh.edu.pl factories in Poland, their beginnings reaching back in time to the thirteenth century.

They are, however, not the only such old mines in Poland. Even older is apparently mining history in Lower Silesia, connected with exploitation of gold and polymetallic ore deposits. Without doubt the beginnings of mining should be bound with search for gold, of which deposits occur in the vicinities of Złoty Stok, Złotoryja, Bolesławiec, Lwówek Ślaski, in Karkonosze, and in the Opawskie Mts. Cretans were most probably the first searchers of this precious metal about $2000 \mathrm{BC}$, and later Celts washed gold-bearing sands in the stream and river valleys. Purely mining activity started in the Middle Ages, in the twelfth and thirteenth centuries, when Złoty Stok, Głuchołazy, Zlate Hory became important centres of exploitation of this precious metal (Dziekoński, 1972). In later centuries most of the old mines were abandoned and/or closed, so presently in many cases their remains are vestigial; filled, and collapsed galleries and chambers, often requiring laborious efforts to reach to them. In the last years works were undertaken in order to make access 
to at least some of these old mines and uncover still legible traces of historic mining in the region.

Since 1970 s the ore mining in the Lower Silesia region is a subject of archaeological works, consisting in searching for, inventory, and recognition of the old mining areas, unveiling the extent of the old mining works, as well as reconstruction of conditions of the exploitation of deposits (Firszt, 2006). In numerous uncovered galleries old timbers are preserved; either as old wooden casings or as elements of old mining machines and devices. Dendrochronological dating of these elements, combined with archaeological, mining, geological, and palaeobotanical studies, would substantially broaden our knowledge about the mining history in the region. Such was the idea of preliminary dendrochronological analyses of wood sampled in selected mines from the eastern part of the Sudety Mts (the Sowie Mts, Kłodzko region, and the Opawskie Mts) in the years 2004-2005.

\section{RESEARCH MATERIALS AND METHODS}

The materials for analyses came fom eight old mines: the gold mine in Złoty Stok, the polymetallic-ore mine in Marcinków, the gold mines in Głuchołazy and Zlate Hory (Czech Republic) as well as old mines in the Sowie Mts (the Silberloch adit, an adit on the on the hillside of Mała Sowa, a graphite mine, and the silver and lead mine Augusta (Fig. 1). The amount and state of preservation of wood in these objects was highly diversified.

\section{The gold mine in Zloty Stok}

The Złoty Stok gold mine belongs to the oldest and most important gold mines in Lower Silesia. The mining works apparently started there in the tenth century, and the first documents concerning mining there date back to 1273. Until the eighteenth century the principal exploited material was gold, which later became only a by-product at the industrial production of the arsenic. The mine con- tinuously functioned until 1961, when it was closed down (Luszczkiewicz and Muszer, 1997). It was re-opened in 1996, but as the Museum of the Gold Mining and Metallurgy. In many galleries and chambers there are preserved relics of wooden casings of walls and ceilings, as well as fragments of shaft timberings. From these wooden remains 33 samples for analyses (mostly in form of slices, in some cases corings) were taken from timberings of mining chambers and shafts in the following parts of the mine: the Prince's Adit, the Black Higher Inclined Drift, the Black Lower Inclined Drift, the Masters' Adit, and the Round Adit (Fig. 2). Generally the timbers were preserved in the mine in a rather bad state; very often wood was cracked, saturated with water and rotten.

\section{The mine in Marcinków}

Another evidence of old mining works in the region is provided by the vestiges of an old mine of polymetallic ores in the village Marcinków, at the foot of the Śnieżnik Massif, near Bystrzyca Kłodzka. The first notes about this mine date back to the sixteenth century (1575). The mine operated, with some interruptions, for more than three centuries and, finally, was definitively closed at the beginning of the twentieth century (Madziarz and Sztuk, 2004). Later, after the Second World War, some attempts of exploitation of uranium ores were undertaken, however, the contents of this element turned out to be insufficient, and the mine in Marcinków was categorised as unprofitable. In the last years two adits, the upper and the lower, were dug out, in which wooden elements of casings of mining galleries as well as an inclined, timbered shaft with a windlass were discovered (SzychowskaKrapiec and Stysz, 2006). These wooden elements were subjected to dendrochronological sampling, carried out with a Pressler increment borer and handsaw for cutting wood (Fig. 3). Altogether 27 slices and cores were taken from both adits.

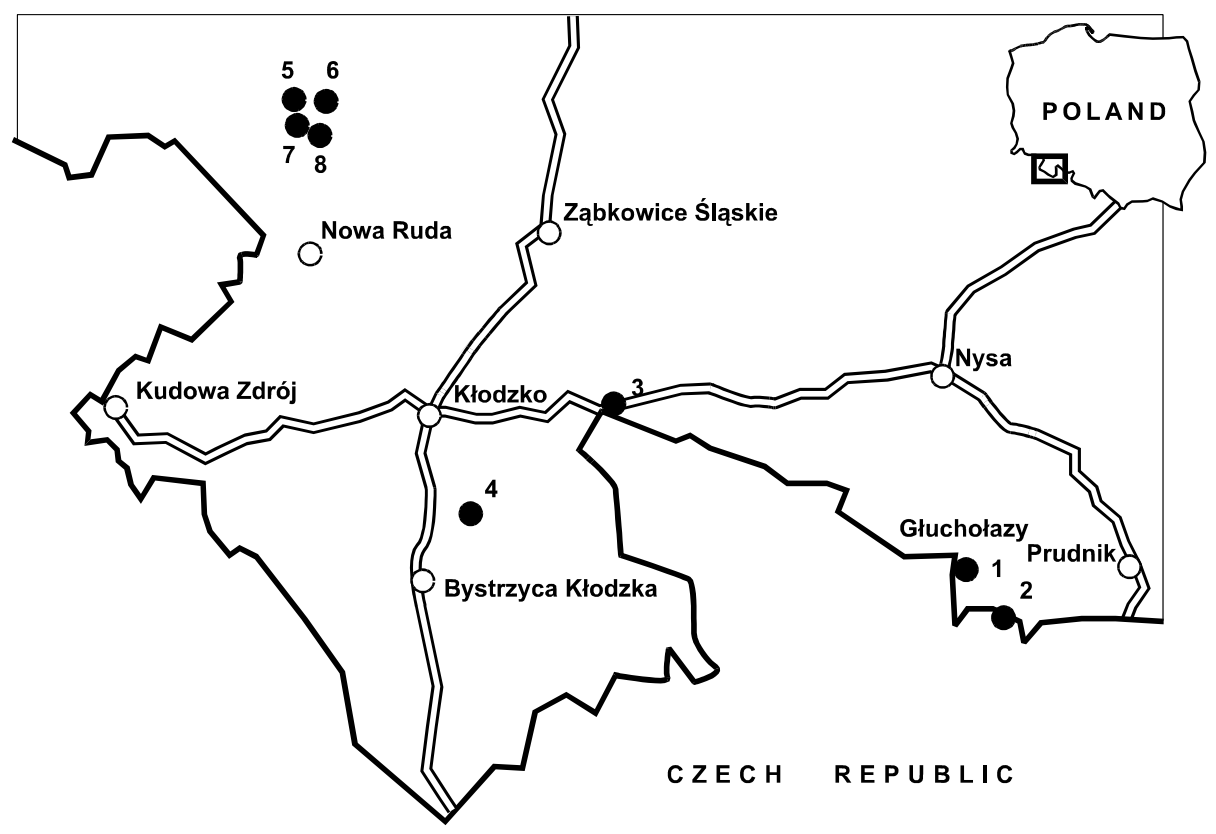

Fig. 1. Locality of the mine objects in which samples were taken for dendrochronological analyses: 1) the gold mine in Głuchołazy, 2) the gold mine in Zlate Hory, 3) the gold mine in Złoty Stok, 4) the mine in Marcinków, 5) the Silberloch adit, 6) the graphite mine in the Sowie Mountains,

7) the mine on the hillside of Mt. Mała Sowa,

8) the Augusta mine. 


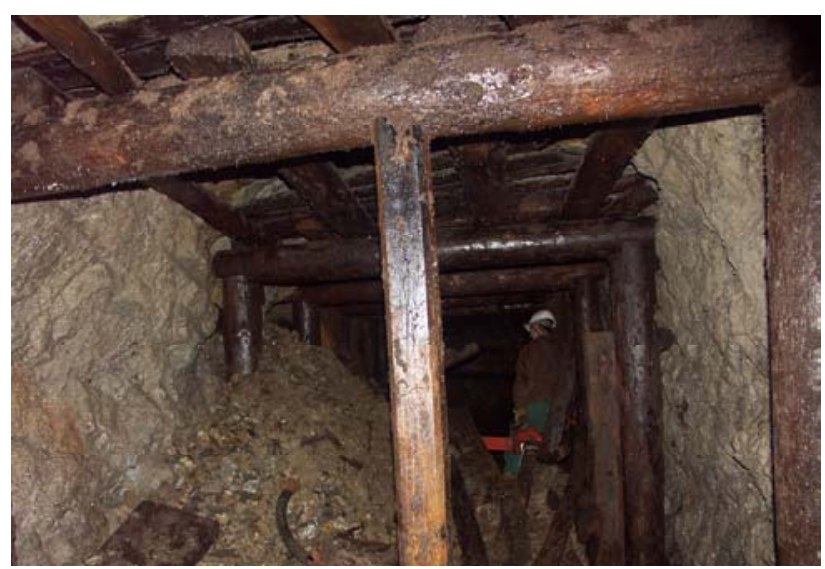

Fig. 2. Wooden casings in the gold mine in Złoty Stok

\section{Gold mines in Glucholazy and Zlate Hory}

In two neighbouring towns in the Opawskie Mountains, Głuchołazy and Zlate Hory, gold mining has a long tradition, closely connected with discovering deposits of this precious metal near Zlate Hory at the beginning of the thirteenth century, which contributed to the development of both towns. Gold was being extracted there in two ways: in open pits and, more often, with a shaft system. In Głuchołazy, up till today about 80 mining shafts are preserved, the biggest of them is about ten metres in diameter and is four metres deep. Gold had been exploited, with some breaks, until the nineteenth century. After the Second World War the mining in this area was reactivated, with exploitation of copper, zinc, and lead ores, as well as up to $30 \mathrm{~kg}$ of the annual production of gold. At present, all the mines have already been closed, but strange events still remind of the mining past. In places of old mines the terrain sometimes collapses, uncovering parts of ancient adits and galleries as well as elements of old wooden casings. From an old timbering this way uncovered, one sample, in form of a slice, was taken for dendrochronological analyses.

The mining past of Zlate Hory, where rich deposits of gold were discovered in the beginning of the thirteenth century, is inseparable from the history of mining in neighbouring Głuchołazy. Shallow deposits were exploited, with some interruptions, till the middle of the nineteenth century. After the Second World War the ore exploitation has been once more undertaken, that time mostly directed at copper, zinc and lead. Gold, as in Głuchołazy, was only a by-product, and the mine in Zlate Hory was definitively closed in 1993. At present fragments of ancient casings can be seen in accessible parts of the mine, where two slices were picked up for analyses.

\section{Mines of polymetallic ores in the Sowie Mountains}

In Lower Silesia not only gold deposits were being exploited but also, among others, ores of arsenic, copper, tin, iron, silver, lead or cobalt. Polymetallic deposits occurred, among others, in the Sowie Mountains, where today over hundred old mines are known. In this region there were exploited e.g. ores of lead and silver, what is

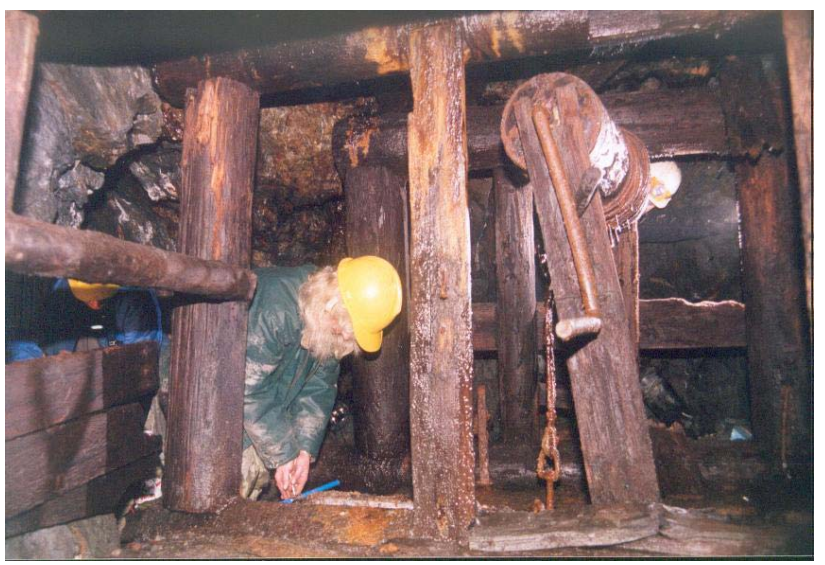

Fig. 3. Taking samples with the Pressler increment borer from the shaft timbering in the Marcinków mine.

still evidenced by common relics after ancient mining; numerous shafts and drifts, mining chambers, galleries, sometimes with fragments of wooden casings and elements of mining machines, some of them reaching back to the fourteenth century (Mączka and Stysz, 2006). To that time dates back the Silberloch adit, at present the best-preserved old-mining object in this massif. The Silberloch was being exploited to the eighteenth century, then, for some time, it functioned as a tourist attraction, showing former mining techniques, ways of accessing deposits for exploitation, as well as draining, ventilation, lighting, and finally transport and further treatment of the ores (Madziarz and Sztuk, 2004). Although few wooden elements, which could be dendrochronologically sampled, are preserved in the adit, two samples, in form of slices, were taken.

In the same massif of the Sowie Mountains one can find an entrance to the ancient graphite mine, with fragments of old wooden casings. From these casings two slices of wood were picked up.

The third dendrochronologically analysed object is a little mine situated between the villages Rzeczka and Walim, on the north-western hillside of Mt. Mała Sowa. This mine is a single gallery, not longer than 30 metres, and in its prevailing part it is flooded with water up to the height of about $40 \mathrm{~cm}$ (Stysz and Mączka, 2005). In the bottom of this gallery a fragment of wood was encountered and sampled (in form of a slice) for dendrochronological analyses.

Also in the Sowie Mountains is situated one of the most beautiful mines - the lead and silver mine Augusta, relatively young, established at the end of the nineteenth century. Its mining area stretches over the commons Kamionki, Pieszyce, and Rościszów. The mine consisted of four levels, some divided with wooden platforms made from beams and boards. On the third level of the mine, close to the gallery heading, traces of an old railtrack were found, with only one retained sleeper, from which a dendrochronological sample was taken (Stysz, 2005).

From all the above-presented mines altogether 69 samples were taken. The investigations were carried out in the dendrochronological laboratory of WGGiOŚ AGHUST in Cracow, the standard methodology (Krapiec, 
1995; Schweingruber, 1988) having been applied. Measurements were made to the nearest $0.01 \mathrm{~mm}$. The obtained sequences of annual growth rings were processed the packages of programs TREE-RINGS (Krawczyk and Krapiec, 1995) and COFECHA (Holmes, 1994). Absolute dating of the sequences produced was carried on the basis of accessible regional standards from Poland, Germany and the Czech Republic for the coniferous tree species. Fir wood was dated against the fir standard for S Poland, embracing the period 1106-1998 AD (Szychowska-Krapiec, 2000), and the Czech chronology (1131-1997 AD) (Kyncl and Kyncl, 1998). In the case of the pine wood, age determinations were based on the regional standard for $\mathrm{N}$ Poland, embracing the period 1106-1991 AD (Zielski, 1997), the Małopolska regional standard (1622-1996) (Szychowska-Krapiec, 1997), the East German regional standard (924-1995 AD) (Heußner, 1996), the local chronologies for Wrocław (1080-1333 AD and 1655-1831 AD) and Lubsko (1254-1376 AD and 1721-1848 AD; Szychowska-Krapiec and Krąpiec, 2001), as well as contemporary local patterns for Bystrzyca Kłodzka (1840-1996), Śnieżka (1837-1996 AD) and Oborniki Śląskie (1872-1989 AD; Zielski et al., 2001). Spruce was dated on the basis of the Czech regional chronology (1279-1997AD; Kyncl pers. comm.), and in the case of the larch wood, hetero-connection with the fir and pine chronologies was applied.

\section{RESULTS}

On the basis of the investigations carried out, the species of wood were determined as well as absolute age determinations were produced. Amongst the examined timbers, exclusively wood of coniferous tree species was determined: Pinus sylvestris, Abies alba, Picea abies and Larix decidua.

\section{The gold mine in Zloty Stok}

The wood sampled for analyses represented three tree species: pine (24 samples), spruce (two samples) and fir (seven samples). Generally, the growth sequences were rather short, consisting of 26-76 rings, most often of 3050 rings. Such short sequences caused serious problems at the absolute dating, especially in the case of spruce samples, dating of which failed.

However, absolute dating of fifteen samples representing pine and fir wood was successful (Table 1). Among them there were six samples of fir. The oldest dates were obtained for wood from the shaft timbering in the Masters' Adit (1667 AD) and for wood coming from the old gun-powder store, also in the Masters' Adit (1751 AD). These timbers were dated against the Czech fir standard, with which they displayed the highest convergence. The younger, nineteenth-century wood was encountered in the Prince's Adit, in the Black Upper In-

Table 1. Results of dendrochronological analysis of wood samples from the gold mine in Złoty Stok

\begin{tabular}{|c|c|c|c|c|c|c|c|}
\hline No & $\begin{array}{l}\text { Lab. } \\
\text { code }\end{array}$ & Locality & Species & $\begin{array}{l}\text { No of tree } \\
\text { rings }\end{array}$ & $\begin{array}{l}\text { Sequence } \\
\text { dating }\end{array}$ & $\begin{array}{r}\text { Date of } \\
\text { felling the } \\
\text { tree }\end{array}$ & $\begin{array}{c}\text { Correlation with } \\
\text { the standard } \\
t \text { and } r \text { values }\end{array}$ \\
\hline 1 & 2ZST1 & Prince's Adit & Pinus sylvestris & 59 & $1883-1941$ & after 1941 & $\begin{array}{l}5.23 \\
0.58\end{array}$ \\
\hline 2 & $3 Z S T 2$ & Prince's Adit & Abies alba & 35 & $1770-1804$ & after 1804 & $\begin{array}{l}4.77 \\
0.65\end{array}$ \\
\hline 3 & 3ZST4 & Black Upper Inclined Drift & Abies alba & 27 & $1859-1885$ & after 1885 & $\begin{array}{l}4.81 \\
0.72\end{array}$ \\
\hline 4 & 2ZST10 & $\begin{array}{l}\text { Black Lower Old Inclined } \\
\text { Drift, behind the fall }\end{array}$ & Pinus sylvestris & 76 & $1809-1884$ & after 1884 & $\begin{array}{l}5.67 \\
0.61\end{array}$ \\
\hline 5 & 2ZST14 & Round Adit, western field & Pinus sylvestris & $40 p$ & $1794-1833$ & 1833 & $\begin{array}{l}4.33 \\
0.49\end{array}$ \\
\hline 6 & 2ZST16 & Masters' Adit & Pinus sylvestris & $53 p$ & $1841-1893$ & 1893 & $\begin{array}{l}4.47 \\
0.54\end{array}$ \\
\hline 7 & 2ZST19 & $\begin{array}{l}\text { Masters' Adit, shaft } \\
\text { timbering }\end{array}$ & Pinus sylvestris & 43 & $1838-1880$ & after 1880 & $\begin{array}{l}4.23 \\
0.51 \\
\end{array}$ \\
\hline 8 & 3ZST21 & $\begin{array}{l}\text { Masters' Adit, shaft } \\
\text { timbering }\end{array}$ & Abies alba & 45 & $1623-1667$ & after 1667 & $\begin{array}{l}4.92 \\
0.59\end{array}$ \\
\hline 9 & 3ZST22 & $\begin{array}{l}\text { Masters' Adit, old gun- } \\
\text { powder store }\end{array}$ & Abies alba & $41 p$ & $1833-1873$ & 1873 & $\begin{array}{l}4.75 \\
0.62\end{array}$ \\
\hline 10 & 3ZST24 & $\begin{array}{l}\text { Masters' Adit, old gun- } \\
\text { powder store }\end{array}$ & Abies alba & 55 & $1697-1751$ & after 1751 & $\begin{array}{l}5.17 \\
0.76\end{array}$ \\
\hline 11 & 2ZST25 & $\begin{array}{l}\text { Masters' Adit, shaft } \\
\text { timbering }\end{array}$ & Pinus sylvestris & 37 & $1848-1884$ & after 1884 & $\begin{array}{l}4.12 \\
0.51 \\
\end{array}$ \\
\hline 12 & 2ZST26 & $\begin{array}{l}\text { Masters' Adit, shaft } \\
\text { timbering }\end{array}$ & Pinus sylvestris & 45 & $1849-1893$ & after 1893 & $\begin{array}{l}4.33 \\
0.49\end{array}$ \\
\hline 13 & $3 Z S T 29$ & Small shaft, sample no 3 & Abies alba & $72 p$ & 1830-1901 & 1901 & $\begin{array}{l}5.21 \\
0.54 \\
\end{array}$ \\
\hline 14 & 2ZST31 & $\begin{array}{l}\text { Gallery under small shaft, } \\
\text { sample no } 5\end{array}$ & Pinus sylvestris & 43 & $1759-1801$ & after 1801 & $\begin{array}{l}4.34 \\
0.47\end{array}$ \\
\hline 15 & 2ZST32 & $\begin{array}{l}\text { Gallery under small shaft, } \\
\text { sample no } 5 \mathrm{~A}\end{array}$ & Pinus sylvestris & 40 & $1748-1787$ & after 1787 & $\begin{array}{l}4.69 \\
0.48\end{array}$ \\
\hline
\end{tabular}


clined Drift, and in the Masters' Adit - in the gun-powder store. The youngest date was obtained for wood from a small shaft - 1901 AD. This dating is precise, because the examined timber retained its last, underbark ring. The younger sequences displayed the highest similarity to the $\mathrm{S}$ Poland standard.

In the case of the pine wood, nine samples were absolutely dated, seven of them to the nineteenth century. The oldest date was produced for wood from a gallery below the small shaft, at the fall of the rock debris - 1787 AD. Another piece of wood from that site was dated to the beginning of the nineteenth century. Since both sequences of annual rings were only fragmentary, devoid of a certain number of the last rings, it may be supposed, that these samples represented pine trees cut down in the same time, i.e. at the beginning of the nineteenth century. A little bit younger, though also from the first half of the nineteenth century, wood was encountered in the Round Adit (1833 AD). The next, still younger dates fell in the second half of the nineteen century; wood from the Black Lower Old Drift, from the site behind the fall was dated to $1884 \mathrm{AD}$, whereas wood from timbering of the flooded shaft in the Masters' Adit came from 1890s. The youngest date was produced for wood from the Prince's Adit 1941 AD (Table 1).

\section{The mine in Marcinków}

The analysed wood represented four coniferous tree species: spruce, fir, pine and larch. The pine samples (18 pieces) substantially outnumbered the other species; seven samples of larch, and only one sample each in cases of fir and spruce. The length of individual sequences varied from about 70 growths at the longest patterns to about 30 at the shortest ones. Most of them exhibited 40-50 growth rings. The dendrochronological analysis carried out enabled dating of eight samples from the upper adit and two from the lower, including seven pine samples and three of larch (Table 2). In the upper adit the oldest date was obtained for pine wood from the timbering (1614 AD). The other dates fell in the nineteenth century, the casings of the upper adit being somewhat older (1808-1815 AD) than the timber from the shaft. The latter pointed at two phases: the older - 1826 $\mathrm{AD}$, and the younger - $1863 \mathrm{AD}$. From the lower adit two pine samples were dated; one represented the tree cut down in $1833 \mathrm{AD}$, and the second tree was felled after 1869 AD. These dates fell in the same time intervals as the dates produced for wood from the upper adit (Table 2).

\section{Gold mines in Gluchołazy and Zlate Hory}

The wood from the mines represented the silver fir. The longest individual sequence, consisting of 83 growth rings, appeared in the wood sample from Głuchołazy, uncovered after the last collapse of the terrain. Shorter sequences were noted at two samples from Zlate Hory; each of them contained 55 increments, including the last, underbark rings. Absolute dating demonstrated that the fir trees represented by the analysed samples were cut down at the end of the fifteenth and at the beginning of the sixteenth century. In the case of wood from the Czech mine the exact dating (with one-year accuracy, thanks to preserved underbark rings) pointed at 1491 AD (Fig. 4). In a little bit younger timber from the mine in Głuchołazy, the last growth ring was dated to $1501 \mathrm{AD}$ (Fig. 5).

\section{Mines of polymetallic ores in the Sowie Mountains}

In the case of wood from four mines in the Sowie

Table 2. Results of dendrochronological analysis of wood samples from the mine in Marcinków.

\begin{tabular}{|c|c|c|c|c|c|c|c|}
\hline No & Lab. code & Locality & Species & $\begin{array}{c}\text { No of } \\
\text { growth rings }\end{array}$ & Sequence dating & $\begin{array}{r}\text { Date of } \\
\text { felling the } \\
\text { tree }\end{array}$ & $\begin{array}{l}\text { Correlation with } \\
\text { the standard } \\
t \text { and } r \text { values }\end{array}$ \\
\hline 1 & 2MARC4 & Shaft, Upper Adit & $\begin{array}{c}\text { Pinus } \\
\text { sylvestris }\end{array}$ & 57 & 1807-1863 & after 1863 & $\begin{array}{l}5.19 \\
0.56 \\
\end{array}$ \\
\hline 2 & 2MARC6 & Upper Adit & $\begin{array}{c}\text { Pinus } \\
\text { sylvestris }\end{array}$ & $55 p$ & 1809-1863 & 1863 & $\begin{array}{l}4.44 \\
0.48 \\
\end{array}$ \\
\hline 3 & 2MARC7 & Upper Adit & $\begin{array}{c}\text { Pinus } \\
\text { sylvestris }\end{array}$ & 41 & $1786-1826$ & after 1826 & $\begin{array}{l}4.19 \\
0.40 \\
\end{array}$ \\
\hline 4 & 2MARC8 & Upper Adit & $\begin{array}{c}\text { Pinus } \\
\text { sylvestris }\end{array}$ & 41 & $1786-1826$ & after 1826 & $\begin{array}{l}4.23 \\
0.48 \\
\end{array}$ \\
\hline 5 & 2MARC11 & Lower Adit & $\begin{array}{c}\text { Pinus } \\
\text { sylvestris }\end{array}$ & 34 & $1836-1869$ & after 1869 & $\begin{array}{l}3.98 \\
0.41 \\
\end{array}$ \\
\hline 6 & 2MARC16 & Lower Adit & $\begin{array}{c}\text { Pinus } \\
\text { sylvestris }\end{array}$ & 36 & $1798-1833$ & after 1833 & $\begin{array}{l}4.46 \\
0.47 \\
\end{array}$ \\
\hline 7 & 2MARC17 & Upper Adit & $\begin{array}{c}\text { Pinus } \\
\text { sylvestris }\end{array}$ & 40 & $1575-1614$ & after 1614 & $\begin{array}{l}4.29 \\
0.47 \\
\end{array}$ \\
\hline 8 & 4MARC1 & Upper Adit & $\begin{array}{c}\text { Larix } \\
\text { decidua }\end{array}$ & 63 & $1748-1810$ & after 1810 & $\begin{array}{l}5.20 \\
0.54 \\
\end{array}$ \\
\hline 9 & 4MARC6 & Upper Adit & $\begin{array}{c}\text { Larix } \\
\text { decidua }\end{array}$ & 61 & $1748-1808$ & after 1808 & $\begin{array}{l}4.98 \\
0.52 \\
\end{array}$ \\
\hline 10 & 4MARC8 & Upper Adit & $\begin{array}{c}\text { Larix } \\
\text { decidua }\end{array}$ & 70 & $1746-1815$ & after 1815 & $\begin{array}{l}5.33 \\
0.56\end{array}$ \\
\hline
\end{tabular}

$p=$ underbark ring 


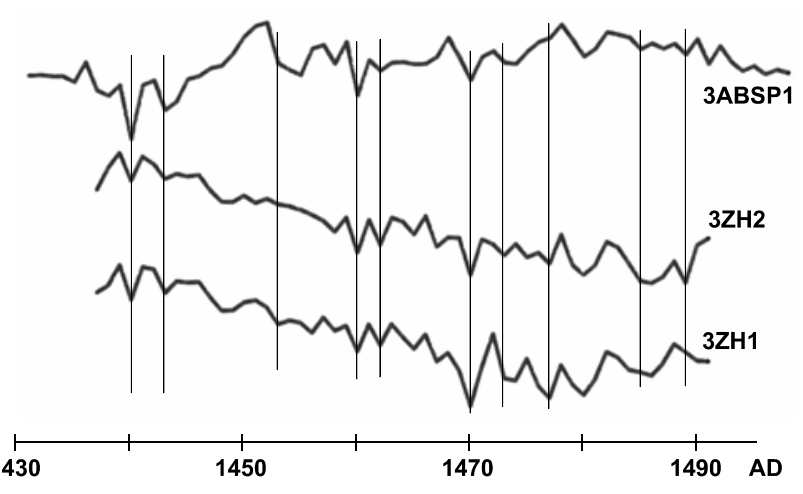

Fig. 4. Dendrochronological dating of fir growth sequences $3 \mathrm{ZH} 1$ and $3 Z \mathrm{H} 2$ from the gold mine in Zlate Hory on the basis of the S Poland standard (3ABSP1).

Mountains, three samples were absolutely dated; from the Silberloch adit, the graphite mine, and the little adit on the hillside of Mt. Mała Sowa. Two timbers sampled in the Silberloch adit turned out to be fir and spruce. Both yielded rather short sequences (51 and 37 growth rings), and both retained the last, underbark ring. Only the fir sample, however, was successfully dated - to 1909 AD (Fig. 6). So, it turned to represent almost contemporary wood, coming from the time when the old mine, having already been closed for two centuries, was only a tourist attraction. Taking into account rather long history of the mine, reaching back to the fourteenth century, older wood could be expected. Low amount of rings in the spruce sample rendered its dating impossible.

Two samples taken from the graphite mine, representing spruce, also had quite short sequences (43 and 63 growth rings). Both, however, retained the last, underbark ring. Dendrochronological dating was successful in the case of one sample - dated to 1672 AD (Fig. 7). This indicates that the analysed wood from that mine came from the spruce cut down in 1672.

The third mine, a sample was taken from, was the lit- tle mine on the hillside of Mt. Mała Sowa. The analysed piece of wood, representing Scots pine, proved to contain 46 annual growths, including the youngest underbark ring. Dendrochronological analysis dated this sample to $1858 \mathrm{AD}(t=5.21, \mathrm{r}=0.67)$ - the exact year of cutting down the pine tree represented by the timber taken from the bottom of the mining gallery.

In the case of wood from the fourth mine, Augusta, dendrochronological analysis could not be successful, because the collected piece of wood contained only 14 growth rings. Only the tree species was determined Picea abies.

\section{DISCUSSION AND CONCLUSIONS}

The dendrochronological investigations carried out in eight mining objects from Lower Silesia resulted in 28 absolute datings of wood samples coming from wooden casings of mining galleries and chambers and mining devices preserved there. The dates obtained range from the fifteenth to the twentieth century. The oldest analysed wood came from the mine in Zlate Hory in the Czech Republic (the end of the fifteenth century) and the mine in Głuchołazy (beginning of the sixteenth century). In both cases it was fir wood. In the gold mine in Złoty Stok, the graphite mine in the Sowie Mountains, and in Marcinków the seventeenth- and eighteenth-century wood was determined. Generally the nineteenth-century wood was prevailing, and in three cases even relatively young, twentieth-century wood was encountered in the mine in Złoty Stok and in the Silberloch adit. The investigations carried out were the first, preliminary dendrochronological studies on wood from the mines from Lower Silesia. They provided, however, hard data, in form of absolute datings of timbers collected there. A broader research would certainly contribute to the mining history and the chronology of mining works in the region Lower Silesia, as it took place in the case of the studies conducted in Austria, in the salt mine in Hallstatt. Den-
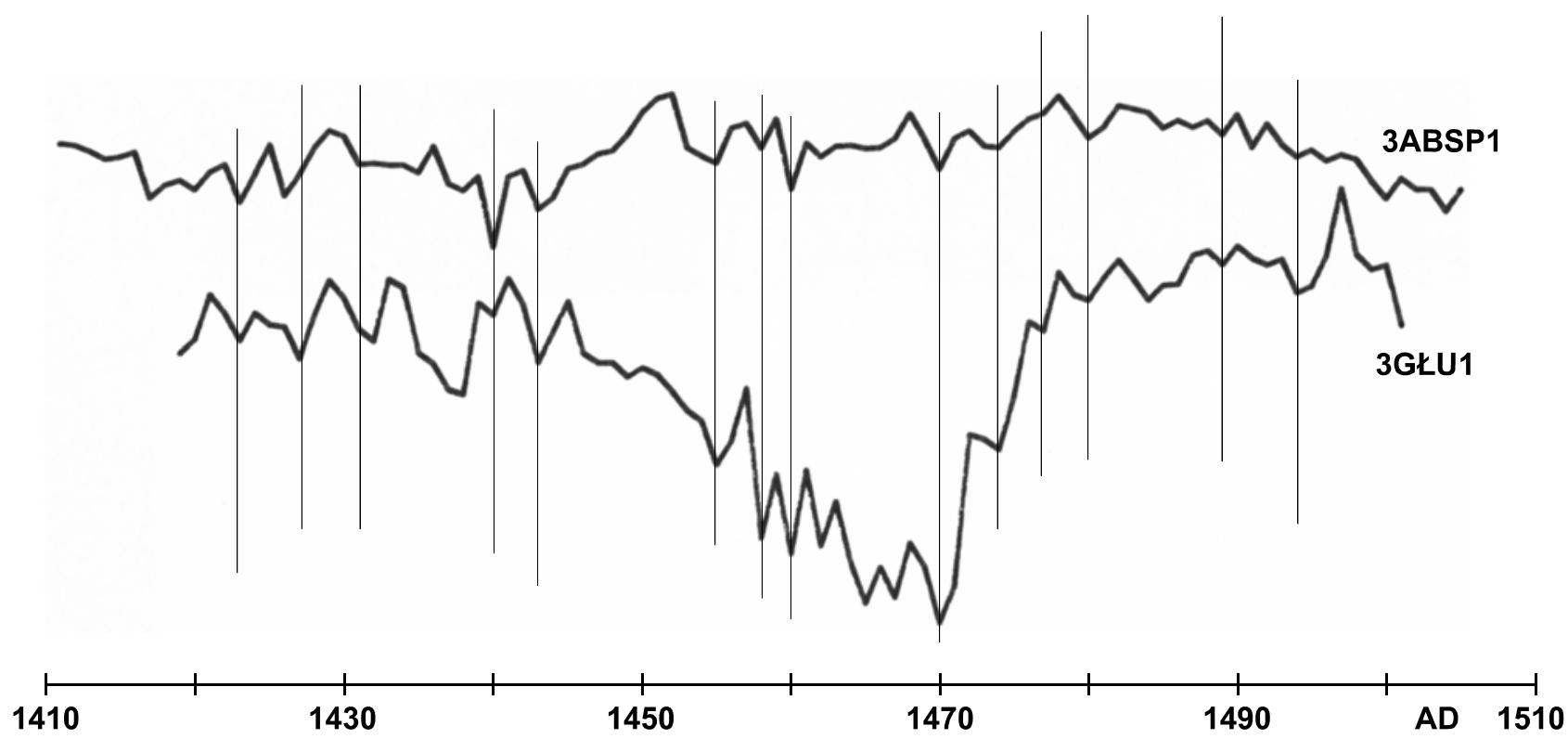

Fig. 5. Dendrochronological dating of fir growth sequence $3 \mathrm{G} Ł U 1$ from the gold mine in Głuchołazy on the basis of the S Poland standard (3ABSP1). 


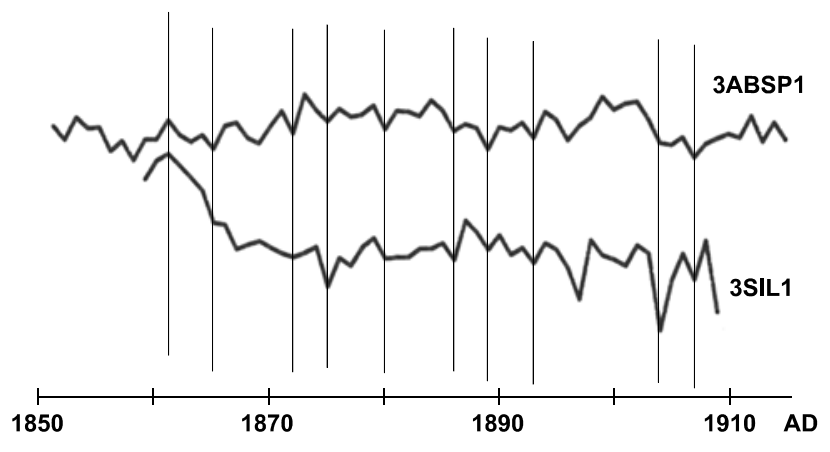

Fig. 6. Dendrochronological dating of fir growth sequence 3SIL1 from the Silberloch mine on the basis of the S Poland standard (3ABSP1).

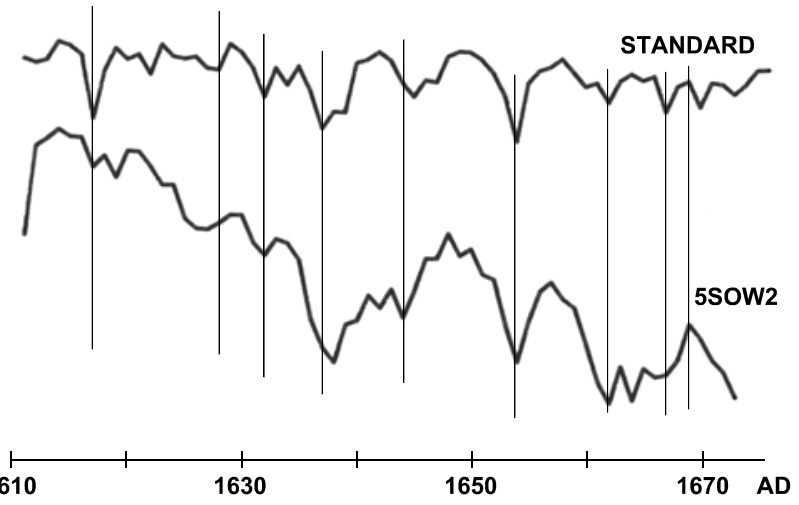

Fig. 7. Dendrochronological dating of spruce growth sequence 5SOW2 from the graphite mine in the Sowie Mountains on the basis of the Czech standard.

drochronological studies in this mine started in 1974, at first on a limited scale, like the investigations presented here, but thanks to continuing them for several consecutive years, they resulted in establishing chronologies for the spruce, larch and fir, enabling to date wooden elements from that site (Grabner et al., 2006; Hollstein, 1974; Ruoff and Sormaz, 1998, 2000).

One should remember that old mines are, in fact, huge stores of wood, representing considerable time intervals, which constitute an excellent base for creating practical dating tools, i.e. dendrochronological standards. Thanks to such local and regional chronologies it is possible to date even single samples containing relatively small numbers of growth rings. The remains of the old mining works in Lower Silesia open such possibilities, because in numerous old mines, shafts, galleries or mining chambers huge amounts of wood are stored.

\section{ACKNOWLEDGEMENT}

The author is grateful to E. Szumska, M. Sc. and M. Stysz, M. Sc. for help at taking samples in the mines. Financial support for this study was provided by the AGH-UST grant no 11.11. 140.917.

\section{REFERENCES}

Dziekoński T, 1972. Wydobywanie i metalurgia kruszców na Dolnym Śląsku (Mining and metallurgy of ores in Lower Silesia). Wydawnictwo PAN, Wrocław, 418 (in Polish).
Firszt S, 2006. Badania archeologiczne nad dolnośląskim górnictwem kruszcowym w latach 1975-2000 (The archeological researches of Lower Silesian ore mining (1975-2000). Prace Naukowe Instytytutu Górn. Politechniki Wrocławskiej, ser. Studia $i$ Materiaty 117(32): 75-79 (in Polish).

Grabner M, Klein A, Geihofer D, Reschreiter H, Barth F, Sormaz T and Wimmer R, 2006. Bronze Age dating of timber the salt-mine at Hallstatt, Austria. Dendrochronologia (in press).

Heußner KU, 1996. Zum Stand der Dendrochronologie im unteren Odergebiet (On the state of dendrochronology in the area of lower Odra). In: S. Moździoch, ed., Man and environment in the Middle and Lower Nadodrze,. PAN, Instytut Archeologii $i$ Etnologii, Spotkania Bytomskie 2: 207-211 (in Polish).

Hollstein E, 1974. Jahrringkurven aus dem Prähistorischen Salzbergwerk in Hallstatt. (Tree ring curves from prehistoric salt mine in Hallstatt) Archäologisches Korrespondenzblatt 4: 49-51.

Holmes RL, 1994. Dendrochronology Program Library. Users Manual. University of Arizona, Tuscon, 51.

Krawczyk A and Krapiec M, 1995. Dendrochronologiczna baza danych (Dendrochronological database). In: Materiaty II Krajowej Konferencji:Komputerowe wspomaganie badań naukowych (Proceedings of II Polish Conference „Computers In Scientific Researches): 247-252. Wrocław (in Polish).

Krapiec M, 1995. Metodyka badań dendrochronologicznych (Methodology of dendrochronological investigation). In: Rutkowski J. and Mycielska-Dowgiało E., eds., Badania osadów czwartorzędowych. Wydawnictwo WGiSR UW. Warszawa: 318-328 (in Polish).

Kyncl J and Kyncl T, 1998. Standardchronologien der Nadelgehőlze. Zeitgemäßifer Zustand in Böhmen und Mähren (Standard chronologies for corniferous trees. Current state in Böhmen und Mähren). Kolloquium "Probleme der mitteleuropäischen Dendrochronologie”. Mikulčice, 1-4.

Łuszczkiewicz A and Muszer A, 1997. Złoto w odpadach górniczych z okolic Złotego Stoku (Gold in mine wastes from Złoty Stok region (SW Poland)). Fizykochemiczne Problemy Mineralurgii 31: 197209 (in Polish)

Madziarz M and Sztuk H, 2004. Kopalnia w Marcinkowie - zapomniane świadectwo wielusetletniej historii eksploatacji górniczej na Dolnym Śląsku (The mine in Marcinków - the forgotten certificate a few hundred history of mine exploatation in the Lower Silesia). Przegląd Górniczy 12(4): 50-55 (in Polish).

Madziarz M and Sztuk H, 2005. Badania stanowisk dawnego górnictwa na terenie Dolnego Ślaska (Exploration of old mining positions at Lower Silesia region). Prace Naukowe Instytytutu Górn. Politechniki Wroctawskiej, ser. Konferencje 111(43): 163-172 (in Polish).

Maczka M and Stysz M, 2006. Relikty dawnych robót górniczych w Górach Sowich - wykorzystanie materiałów archiwalnych do lokalizacji i udokumentowania wyrobisk (The relics of past mining activities in Sowie Mountains - the use of archive data for the excavations locating and documentating). Prace Naukowe Instytutu Górn. Politechniki Wrocławskiej, ser. Studia i Materiały 117(32): 215-226 (in Polish).

Ruoff U and Sormaz T, 1998. Dendrochronologische Untersuchungen von Proben aus den keltischen Salzberwerken vom Dürmberg bei Hallein und Hallstatt (Dendrochronological studies samples from Celtic main from Dürmberg near Hallen and Hallstatt). Archäologisches Korrespondenzblatt 28: 75-76.

Ruoff $U$ and Sormaz T, 2000. Eisenzeitliche Dendrodaten aus dem Salzbergwerk Hallstatt (Ostgruppe) (Dendrodata from Iron period from main in Hallstatt). Archäologisches Korrespondenzblatt 30: 403-408.

Schweingruber FH, 1988. Tree-rings. Basic and applications in dendrochronology. Reidel, Dortrecht, 276pp.

Stysz M, 2005. Kopalnia Augusta (The Augusta mine). Sudety 48(3): 18-22 (in Polish).

Stysz M and Maczka M, 2005. Historia górnictwa Walimia i Rzeczki (The history of mining in Walim and Rzeczka). Sudety 50(5): 2831 (in Polish).

Szychowska-Krąpiec E, 1997. Dendrochronological pine scale (16221996 AD) for the Małopolska area (South Poland). Bulletin of the Polish Academy of Sciences. Earth Sciences 45: 1-13.

Szychowska-Krąpiec E, 2000. Późnoholoceński standard dendrochronologiczny dla jodły Abies alba Mill. z obszaru południowej Polski (The Late Holocene master chronology of fir Abies alba Mill. From southern Poland). Zeszyty Naukowe AGH, Geologia 26(2):173-299 (in Polish). 
Szychowska-Krapiec E, 2003a. Application of Dendrochronological Analysis in Dating of Timbers from the Wieliczka Salt Mine. Bulletin of the Polish Academy of Sciences. Earth Sciences, 51(2): 99118.

Szychowska-Krapiec E, 2003b. Przykład wykorzystania analizy dendrochronologicznej w datowaniu obudów górniczych w Kopalni Soli w Bochni (Dendrochronological dating of timbers wood in the gold mine from Złoty Stok). Sylwan CXLVII (9): 47-52 (in Polish).

Szychowska-Krapiec E and Krąpiec M, 2001. Dendrochronological studies on construction of pine (Pinus sylvestris L) standard for SW Poland. Geochronometria 20: 51-56.
Szychowska-Krapiec E and Stysz M, 2006. Analiza dendrochronologiczna drewna ze sztolni w Marcinkowie (Dendrochronological analysis of wood from Marcinków adits). Prace Naukowe Instytutu Górn. Politechniki Wrocławskiej, ser. Studia i Materiaty 117(32): 289-302 (in Polish).

Zielski A, 1997. Uwarunkowania środowiskowe przyrostów radialnych sosny zwyczajnej (Pinus sylvestris L.) w Polsce północnej na podstawie wielowiekowej chronologii (Environmental conditions of radial growth of Pinus sylvestris from North Poland on the basis of long time chronology). UMK Torun 127 (in Polish).

Zielski A, Krąpiec M, Wilczyński S and Szychowska-Krąpiec E, 2001. Chronologie przyrostów radialnych sosny zwyczajnej w Polsce (Chronologies of radial growth of Scots pine in Poland). Sylwan CXLV (5): 105-119 (in Polish). 